\title{
Habitat Use and Fecal Analysis of Feral Burros (Equus asinus), Chemehuevi Moun- tains, California, 1974
}

\section{SUSAN L. WOODWARD AND ROBERT D. OHMART}

Highlight: Between January and March burros spent from 60 to $78.7 \%$ of their time on the interfluves. In April, habitat use was predominantly in washes, with a high of $58.5 \%$ in July. During the summer months, when daily maximum ambient temperature ap. proached $48^{\circ} \mathrm{C}$, much of their time was spent in densely shaded pockets of vegetation along the Colorado River.

Thirty-nine plant species comprised the diet in 1974, desert Indianwheat (Plantago insularis) and palo verde (Cercidium floridum) being the most common. These two species, combined with mesquite (Prosopis spp.) and arrowweed (Pluchea sericea) formed over 50\% of the annual diet. The 1974 diet consisted of $3.9 \%$ grasses, $30.1 \%$ forbes, and $61.1 \%$ browse.

Population increases of 20-25\% every 13-18 months and little predation bespeaks the need for unceasing management and possible control to prevent deterioration of the native flora and fauna.

The feral burro (Equus asinus) is considered a pest by many in several western states, yet little information is presently available on diet and habitat preference. Browning (1960) presented data from 20 stomach samples representing spring and fall diets in Cottonwood Canyon, Death Valley National Monument. McMichael (1964) reported on the analysis of 9 stomach samples collected in the spring and summer in the Black Mountains, northwestern Arizona. Hansen and Martin (1973) analyzed burro dung collected in the western end of the Grand Canyon and assumed the sample constituted the annual diet. In the present study, fresh dung was collected monthly for microscopic analysis to determine the annual diet of burros in the Chemehuevi Mountains.

\section{Study Area}

The Chemehuevi Mountains are located approximately $15 \mathrm{~km}$ south of Needles, Calif., on the western bank of the Colorado River. An

Authors are with the Department of Zoology or Center for Environmental Studies, Arizona State University, Tempe 85281 .

Dr. R. M. Hansen kindly allowed S. L. Woodward to train in his Composition Analysis Laboratory at Colorado State University, where the time and instruction given by Mrs. T. M. Foppe was greatly appreciated. We thank Mrs. J. Wen and S. Brown of Arizona State University for the fecal analysis reported here. Dr. R. M. Hansen and Dr. R. J. Raitt, Jr., New Mexico State University, reviewed the manuscript.

Miss Woodward was supported by an AAUW Graduate Fellowship for Women, 197374. Field research and laboratory anaysis were funded by Bureau of Land Management grant number 52500-CT4-270. The Rocky Mountain Forest and Range Experimental Station on the Arizona State University Campus provided space and laboratory equipment for the fecal analysis work.

Manuscript received December 24, 1975. estimated 80 burros inhabit the deeply dissected bajadas flanking the mountain range at elevations of 150 to 250 meters above sea level. The sparse desert vegetation of the interfluves is characterized by creosotebush (Larrea divaricata), brittlebush (Encelia farinosa), and burrobush (Ambrosia dumosa) with scattered chollas (Opuntia acanthocarpa) and ocotillos (Fouquieria splendens). A variable cover of ephemerals forms after a rain. Among these forbs, desert Indianwheat (Plantago insularis) is an abundant species.

Vegetation of the washes is dominated by palo verde (Cercidium floridum), desert lavender (Hyptis emoryi), catclaw (Acacia greggii), wolfberry (Lycium andersonii), sweet bush (Bebbia juncea), and burroweed (Hymenoclea salsola).

Influenced by the high water table adjacent to the Colorado River, discontinuous pockets of riparian vegetation have formed at the mouths of the larger washes. The exotic saltcedar (Tamarix chinensis), screwbean mesquite (Prosopis pubescens), and, to a lesser extent, honey mesquite $(P$. juliflora) form dense thickets surrounded on their landward edge by narrow belts of arrowweed (Pluchea sericea).

Seasonal springs and seeps support various elements of the riparian vegetation, as well as sparse stands of annual grasses. Grasses, both annual and perennial, were essentially absent from other habitats within the study area. The ephemeral water sources rarely provided drinking water for burros during 1974. In a region where the annual precipitation averages $114 \mathrm{~mm}$, the Colorado River is the only permanent source of water.

\section{Methods}

Field observations on habitat use were amassed throughout a yearlong study of the microdistributional patterns of feral burros in the Chemehuevi Mountains (Woodward, 1976). During the daylight hours of at least 15 days each month of 1974, the habits and movements of marked, free-roaming burros were recorded. Each time a burro was sighted, it was noted in which type of habitat it occurred. Each individual observation was considered a hit in order to calculate frequency of habitat use.

Fresh feces were collected whenever it was possible to do so without disturbing burros under observation. Composite samples for each month were analyzed at the Fecal Composition Analysis Laboratory, Arizona State University. Twenty random microscope fields were read on each of 20 slides for each month. Plant fragments were matched to those in a reference slide collection made from plants collected in the Chemehuevi Mountains. Frequency of occurrence of each identifiable species was converted to percent relative density, which has been determined to be similar to the percent dryweight composition (Sparks and Malechek, 1968).

\section{Results}

The percent frequency with which burros were observed in 


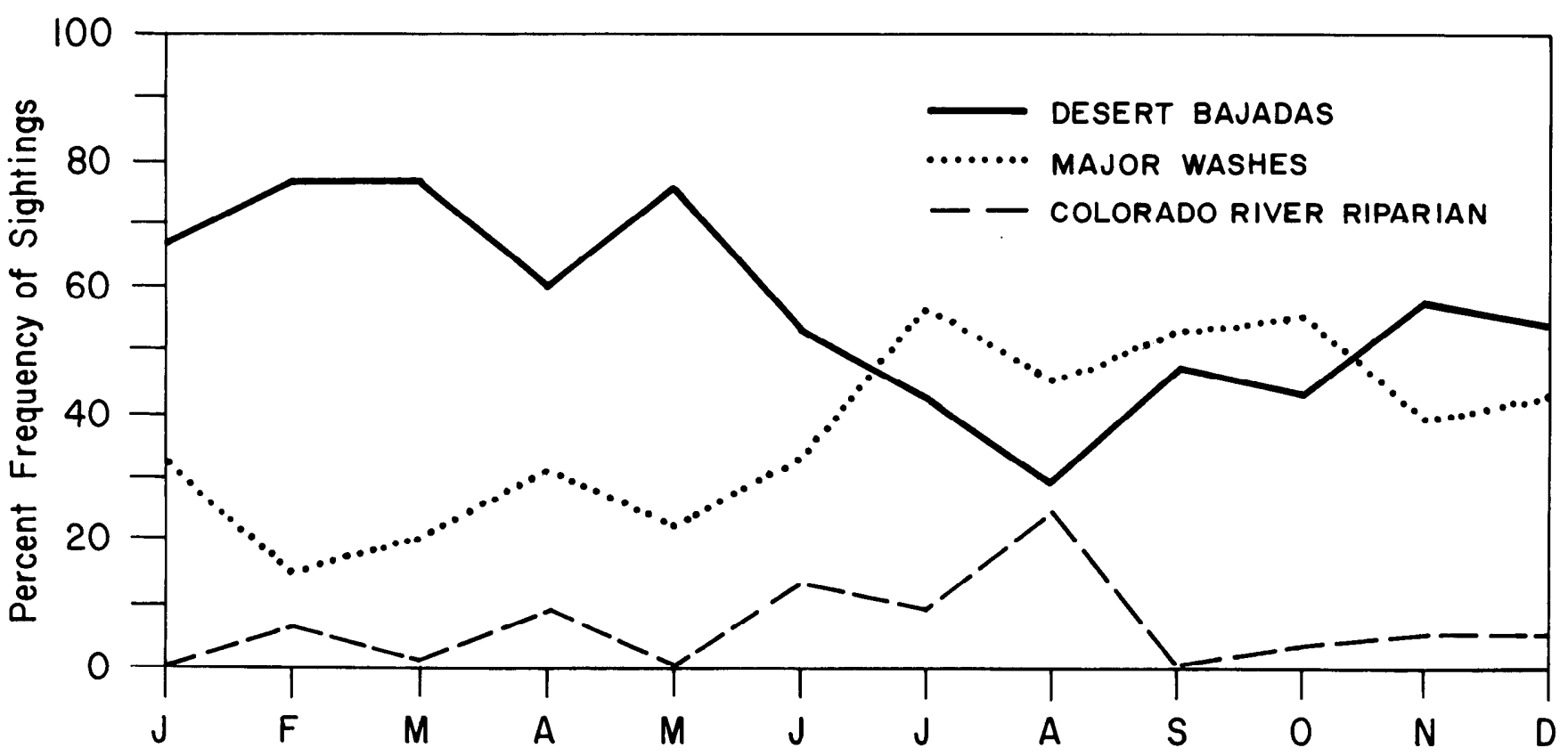

Fig. 1. Percent frequency of sightings of feral burros in three types of habitat in the Chemehuevi Mountains, Calif., 1974.

the three types of habitat (Fig. 1) gives a general view of habitat use throughout the year. Burros were observed between 60 (January) and 78.7 (March) percent of the time on the interfluves during the winter months. Major washes were used only as avenues of travel to the Colorado River for water. When the trek was made (at approximately 3-day intervals) little time was spent foraging in the arroyos. The burros proceeded at a steady pace of 2 miles an hour downstream to the water's edge. They drank uninterruptedly for about 2 minutes, then paused only 10 to 20 minutes in the riparian zone before heading upstream and back onto the interfluves. Much of the ten or more minutes spent in the riparian zone was used to consume the salt-encrusted soil beneath saltcedars. No browsing was observed in the riparian habitat during the winter. If water was available in tinajas, springs, or channel gravels of washes, burros did not visit the river or the riparian vegetation.

Movement was highly restricted in January through March. The distance covered by an individual burro in the course of a day was often less than $1.5 \mathrm{~km}$. A given group of burros (usually 2 to 5 animals) could often be located the following day within 0.75 to $1.5 \mathrm{~km}$ of where they had been observed the previous evening.

With the approach of spring (April) and summer (June) and the greening of perennials, burros began to spend more time foraging in the washes. By July, burros were rarely seen on the interfluves after dawn, and $58.5 \%$ of observed burros were sighted in the washes. At that time ambient temperatures reached $48^{\circ} \mathrm{C}$ in the afternoons, and burros sought shade under palo verdes, mesquites, and saltcedars. The typical diurnal pattern of movement was for burros to move into the washes early in the morning (0600 to 0700 hours) and to reach the mouths of the washes by midmorning (0900 to 1000 hours). They spent all day hidden in the pockets of saltcedar and mesquite which edge the Colorado River. At about 1730 hours, the burros moved back into the washes and grazed and browsed until dark, slowly working their way upstream. At dawn they could be found on the interfluves 1.5 to $3.0 \mathrm{~km}$ from the river.

As the weather cooled in September and October, burros abandoned the riparian zone for the washes. Probably because of 2 years of drought and the subsequent removal of cured annuals, burros spent less time on the interfluves in December 1974 than in the previous January. When a sparse cover of winter annuals sprouted in March and April, 1975, burros were again observed over $60 \%$ of the time on the interfluves.

Thirty-nine plant species (including four unknowns) were identified in the burro diet for 1974 (Table 1). Desert Indianwheat and palo verde were by far the most common items. Together with arrowweed and mesquite, they formed over $50 \%$ of the annual diet. Prominence in the diet varied seasonally among these four elements. The annual desert Indianwheat responds only to winter precipitation. When it sprouted and was abundant between February and June, it formed the bulk of the diet (Fig. 2). Arrowweed and palo verde gained dominance (each contributing over $15 \%$ of the diet) as the annual forb layer was depleted and as warmer weather kept the burros close to the river in late May and June. In July and August, mesquite was a principal food item, and desert Indianwheat lost its importance. This change reflects in part the high temperatures which kept burros in the riparian zone, but also the ripening and dropping of

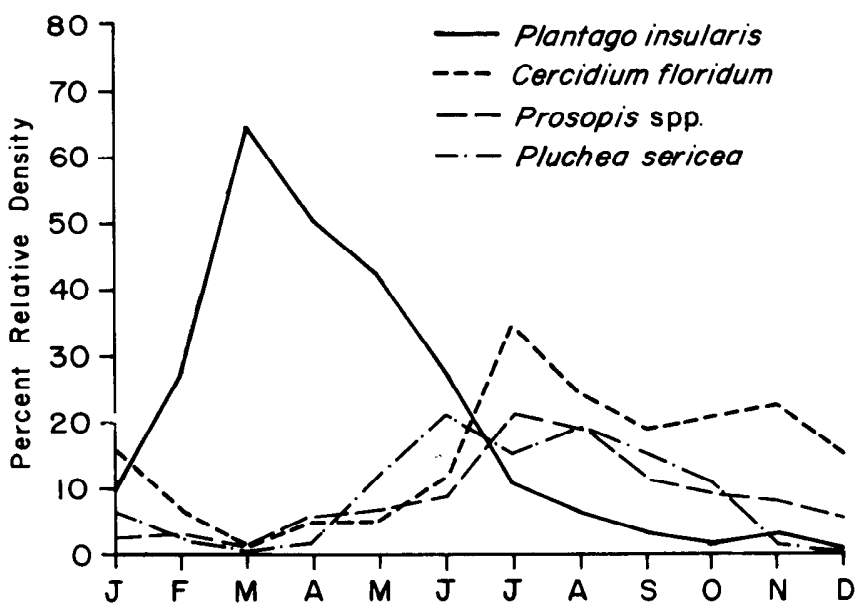

Fig. 2. Percent relative density of the four major plant species in the diet of burros in the Chemehuevi Mountains, Calif., 1974. 
Table 1. Percent relative density of plant fragments found in feral burro dung, Chemehuevi Mountains, California, $1974 .{ }^{1}$

\begin{tabular}{|c|c|c|c|c|c|c|c|c|c|c|c|c|c|}
\hline Species & $\begin{array}{l}\text { Jan. } \\
(17)\end{array}$ & $\begin{array}{c}\text { Feb. } \\
(4)\end{array}$ & $\begin{array}{c}\text { Mar. } \\
\text { (3) }\end{array}$ & $\begin{array}{c}\text { Apr. } \\
\text { (8) }\end{array}$ & $\begin{array}{c}\text { May } \\
(8)\end{array}$ & $\begin{array}{c}\text { June } \\
(5)\end{array}$ & $\begin{array}{l}\text { July } \\
\text { (13) }\end{array}$ & $\begin{array}{c}\text { Aug. } \\
\text { (3) }\end{array}$ & $\begin{array}{c}\text { Sep. } \\
\text { (2) }\end{array}$ & $\begin{array}{c}\text { Oct. } \\
(9)\end{array}$ & $\begin{array}{c}\text { Nov. } \\
(6)\end{array}$ & $\begin{array}{l}\text { Dec. } \\
\text { (11) }\end{array}$ & Annual \\
\hline \multicolumn{14}{|l|}{ Grasses } \\
\hline Threeawn (Aristida spp.) & & 0.3 & 0.6 & 0.5 & & & & & & 1.2 & 0.3 & & 0.2 \\
\hline Bush muhly (Muhlenbergia porteri) & & 0.3 & & & & & 2.0 & & & 4.4 & 0.2 & 12.4 & 1.6 \\
\hline Red brome (Bromus rubens) & & & & 1.5 & 0.2 & & & & & & 0.2 & & 1.9 \\
\hline Schismus barbatus & & & 1.4 & 4.8 & & & & & & & & 0.3 & 0.5 \\
\hline Desert fluff grass (Tridens pulchellus) & & & & 0.3 & & & & & & & 0.2 & & $\mathrm{~T}$ \\
\hline Sorghum spp. & & 0.6 & 0.2 & 0.6 & & & & 2.4 & 2.3 & 7.0 & 2.0 & 1.6 & 1.4 \\
\hline Total grasses & 0.0 & 1.2 & 2.2 & 7.7 & 0.2 & 0.0 & 2.0 & 2.4 & 2.3 & 12.6 & 2.9 & 14.3 & 3.9 \\
\hline \multicolumn{14}{|l|}{ Forbs } \\
\hline Wild buckwheat (Eriogonum spp.) & 0.5 & 5.8 & 0.7 & 0.3 & 3.1 & 4.8 & & & & 3.8 & 1.3 & 0.6 & 1.7 \\
\hline Wishbone bush (Mirabilis bigelovii) & & & & & 0.9 & & & & & & & & 0.1 \\
\hline Blazing star (Mentzelia spp.) & & & 0.4 & & & & & & & & & & $\mathrm{~T}$ \\
\hline Evening primrose/Sun drops (Oenothera spp.) & 0.3 & 0.8 & 7.9 & 3.5 & & & & & & 0.5 & & 0.1 & 1.1 \\
\hline Bristly gilia (Langloisia setosissima) & & 0.3 & & & & & & & & & & & $\mathrm{~T}$ \\
\hline Comb-bur (Pectocarya spp.) & & & & & & & & & & & 0.3 & 0.3 & 0.1 \\
\hline Fiddleneck/Forget-me-not (Amsinckia/Cryptantha) & 7.9 & 7.3 & 4.0 & 3.2 & 4.0 & 5.1 & 1.3 & 7.3 & 5.5 & 2.0 & 2.5 & 5.0 & 4.6 \\
\hline Monkeyflower (Mimulus bigelovii) & 4.0 & 4.9 & & & & & & & & & 3.5 & 4.0 & 1.4 \\
\hline Desert Indeanwheat (Plantago insularis) & 10.0 & 26.9 & 64.4 & 50.4 & 41.9 & 27.3 & 10.8 & 6.6 & 2.9 & 1.7 & 3.3 & 0.5 & 20.6 \\
\hline Desert sunflower (Geraea canescens) & & 0.3 & & 0.3 & 2.0 & & & & & & & & 0.2 \\
\hline White tackstem (Calycoseris wrightii) & & 0.6 & & 0.5 & & & & & & & & 0.7 & 0.2 \\
\hline Total forbs & 22.7 & 46.9 & 77.4 & 58.2 & 51.9 & 37.2 & 12.1 & 13.9 & 8.4 & 8.0 & 10.9 & 11.2 & 30.1 \\
\hline \multicolumn{14}{|l|}{ Browse } \\
\hline Palo verde (Cercidium floridum) & 16.1 & 6.1 & 1.0 & 2.3 & 3.0 & 11.8 & 34.2 & 24.7 & 18.8 & 20.6 & 22.0 & 15.5 & 14.7 \\
\hline Desert senna (Cassia armata) & & 0.3 & & & & 1.4 & & & & & & & 0.1 \\
\hline Mesquite (Prosopis spp.) & 2.3 & 2.5 & 0.6 & 4.6 & 6.1 & 8.6 & 21.3 & 19.6 & 11.8 & 9.1 & 8.0 & 5.6 & 8.3 \\
\hline Catclaw acacia (Acacia greggii) & 5.0 & & 1.2 & 1.3 & 2.4 & 0.6 & & 3.0 & 3.5 & 11.8 & 13.7 & 9.2 & 4.3 \\
\hline Indigobush (Dalea schottii) & 3.9 & 1.7 & 0.2 & & & & & & & & 3.3 & 5.5 & 1.2 \\
\hline White ratany (Krameria grayi) & 0.8 & 0.8 & & 5.2 & 3.2 & 6.7 & 3.4 & 2.7 & & 1.4 & & 0.3 & 2.0 \\
\hline Creosotebush (Larrea divaricata) & & 1.7 & 2.9 & 2.0 & & & & & 3.6 & & & 1.3 & 1.0 \\
\hline Globemallow (Sphaeralcea ambigua) & 1.9 & & & & & & & & & & 1.8 & 0.3 & 0.3 \\
\hline Ocotillo (Fouquieria splendens) & 4.2 & 6.1 & 2.4 & 1.1 & 0.9 & 0.9 & 3.1 & 1.8 & 2.1 & & 4.5 & 2.4 & 2.5 \\
\hline Cholla or pricklypear (Opuntia spp.) & 7.6 & 1.1 & 2.8 & 2.5 & 3.8 & & & & 8.7 & 2.4 & 7.3 & 2.0 & 3.2 \\
\hline Desert lavender (Hyptis emoryi) & 0.4 & 0.3 & & 0.2 & & 1.2 & & 0.3 & & & & 0.1 & 0.2 \\
\hline Anderson wolfberry (Lycium andersonii) & 2.6 & 3.5 & 0.1 & 0.8 & & 0.5 & & & 7.5 & & 7.4 & 0.7 & 1.9 \\
\hline Burro brush (Hymenoclea salsola) & 6.4 & 4.0 & 4.2 & 5.9 & 1.0 & 4.4 & 4.6 & 5.5 & 7.1 & 10.9 & 8.4 & 5.9 & 5.7 \\
\hline Brittlebush (Encelia farinosa) & 3.3 & & & 1.0 & 1.6 & 0.8 & & & & & & 2.2 & 0.7 \\
\hline Arrowweed (Pluchea sericea) & 6.2 & 2.2 & 0.7 & 2.0 & 12.0 & 21.1 & 15.7 & 19.0 & 15.1 & 10.4 & 1.7 & & 8.8 \\
\hline Burrobush (Ambrosia dumosa) & 12.8 & 3.7 & 3.4 & 2.0 & 4.1 & & & 2.2 & & 5.8 & 4.8 & 18.3 & 4.8 \\
\hline Sweet bush (Bebbia juncea) & 0.3 & 2.0 & & 3.2 & & & & & 1.6 & & & 3.5 & 0.9 \\
\hline Desert fir (Peucephyllum schottii) & & & & & & & & & 4.0 & 1.6 & & 0.3 & 0.5 \\
\hline Total browse & 73.8 & 36.0 & 19.5 & 34.1 & 38.1 & 58.0 & 82.3 & 78.8 & 83.8 & 74.0 & 82.9 & 73.1 & 61.1 \\
\hline Unknowns & 3.5 & 15.9 & 0.9 & 0.0 & 9.8 & 4.8 & 3.6 & 4.9 & 5.5 & 5.0 & 2.3 & 1.4 & 4.9 \\
\hline
\end{tabular}

Numbers in parentheses are sample sizes.

mesquite beans and the paucity of annuals. With the lower temperatures of autumn, the two riparian species (arrowweed and mesquite) lessened in importance; but palo verde remained heavily utilized throughout the latter half of the year. The drop in palo verde in December was compensated for by a marked increase to $18.3 \%$ in the consumption of burrobush, which had responded to a November rainfall.

\section{Discussion}

The 1974 diet of feral burros in the Chemehuevi Mountains consisted of $3.9 \%$ grasses, $30.1 \%$ forbs, and $61.1 \%$ browse. An additional $4.9 \%$ was unknown species, three of which were undoubtedly winter annuals overlooked in plant collecting. Published analyses of burro diets from other localities indicate a lesser dependence on browse than in the Chemehuevi Mountains, but none of these studies truly presents an annual diet. From fall and spring stomach samples, Browning (1960) determined the annual diet of burros in Death Valley to consist of $10.0 \%$ grasses, $39.0 \%$ forbs, and $51.0 \%$ browse. Using the same fecal composition analysis methods employed in the
Chemehuevi study, Hansen and Martin (1973) data reveal the annual burro diet in the western Grand Canyon to contain $61.0 \%$ grasses, $11.5 \%$ forbs, and $27.5 \%$ browse species. The latter study was based on 50 random samples of dried burro dung with no guarantee, however, that it was deposited over the course of an entire year. If Hansen and Martin's data should represent the annual diet of burros using a small, restricted area in the lower Grand Canyon, then the variations between their results and ours may merely reflect a difference in plant species composition between the two study areas and illustrate the versatility of the feral burro and the unspecialized nature of its food habits.

Burros may prefer grasses and forbs, as suggested by the heavy use of desert Indianwheat while it was available. The plant species composition of our study area, however, forces them to be predominantly browsers and to be highly opportunistic in their diet. Plant species variety in the diet of burros in the Chemehuevi Mountains reflects the diversity of plants germinating or leafing out in response to sporadic precipitation. The greatest variety of plants occurred in the diet in February (28 species), April (25 species), and December (27 species). Each of these months was preceded by a month in which some rain 


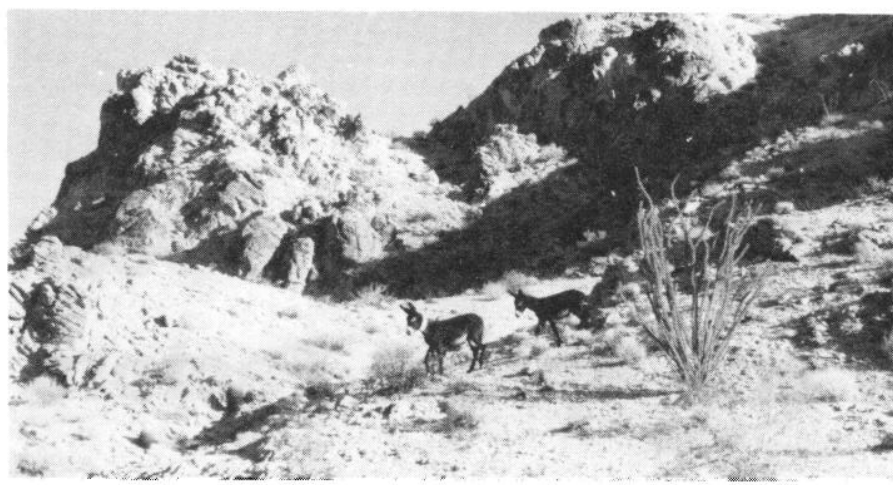

Fig. 3. Interfluval area, Chemehuevi Mountains, Calif., showing sparse perennial vegetation and the absence of the annual herbaceous layer that has been grazed off by burros.

fell. Also, each was a relatively cool month, during which burros could have ranged over a wide area and visited springs and seeps which are located several miles from the river and near which forbs and grasses are most likely to occur. The least variety in the diet occurred in July (10 species) and August (13 species), when burros were essentially confined to the banks of the Colorado River.

The dramatic decline in desert Indianwheat did not reflect a lack of interest in the species by burros. As seen in Figure 1, burros spent considerable time grazing on the interfluves in the fall and winter months (Figs. 3 and 4). Desert Indianwheat was the primary food item on the slopes, but it had been severely depleted by the burros' constant grazing. Search time must have greatly increased as the year progressed and the density of the annual declined. Indeed, observations of marked burros were much more sporadic in the winter of 1974-75 than in 1973-74, as the burros were forced to move more widely and more frequently in search of forage.

Palo verde did not seem to be preferred in its green, leafy state. Perhaps it is ingested to satisfy some desire for bulk. Field observations indicate that most of the palo verde eaten was in the form of yellowed twigs and branches up to $2.5 \mathrm{~cm}$ in diameter. Nearby green branches were often ignored. Similarly, cured burroweed also seems to be preferred over green specimens of the same species. Burros were observed eating skeletons of dead cholla as well as green joints.

Although the carrying capacity of the desert for feral burros is unknown, it does not appear to have been exceeded in the Chemehuevi Mountains. (This is not to imply that other herbivorous species are not affected until burros reach carrying capacity - for they may well be.) The present vegetation shows few overt signs of burro overgrazing. It may well be that perennial grasses have been eliminated by burros as Weaver (1972) maintains. In the absence of an historical record, there is no way to substantiate which plant species may have been eradicated. That the annual Plantago layer is grazed off each year is of little significance as long as winter rains revitalize the slopes. Herbaceous species appear to prefer Plantago in the cured form, which appears to have little impact on seed dissemination. In periods of extended drought, shrubs will incur heavier browsing pressure. However, except under prolonged drought conditions, it appears unlikely that permanent damage to the vegetation will result-at least at the present size of the burro population. Desert shrubs demonstrate great regenerative powers when the unusually wet year comes. Effects on native fauna during drought may be much more severe than that on the flora.

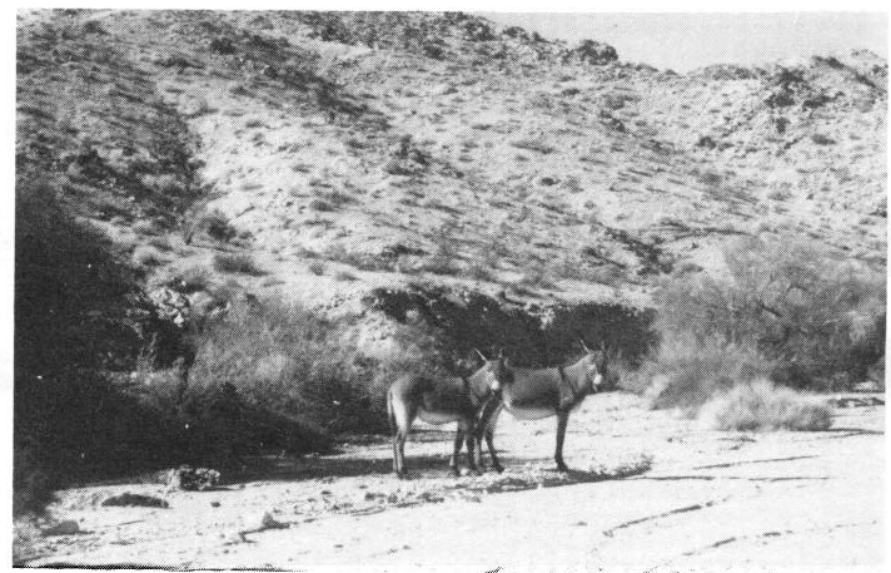

Fig. 4 Trampas Wash in the Chemehuevi Mountains, Calif. Palo verde tree on the right and sparce creosotebush covering the hillside in the background.

Ocotillo received some of the heaviest destruction from burros. The long, whip-like branches were broken off, the bark and cambium stripped. However, in most instances, new branches sprouted beneath the injuries, giving the ocotillo a bushy physiognomy. In time a protective thorn hedge may develop, protecting a few central spires, which can flower and set seed.

Palo verdes within $0.5 \mathrm{~km}$ of the Colorado River show definite browse lines at heights of about $1.5 \mathrm{~m}$. Cattle, as well as burros, are responsible for this condition. Reproduction of the trees does not appear to be impaired, and young palo verdes can be found.

Occasional burrobushes were browsed to the ground. Nearby there were robust specimens, apparently untouched. The few dead burrobushes appeared to have been old individuals, as evidenced by their thick, gnarled stems.

The immediate removal of annuals by burros and the ever increasing browsing pressure on the perennial plant species by dense burro populations might act similarly to prolonged drought in that plant health would continually decline, while precluding the possibility of respite afforded by aperiodic wet winters. During the course of our study we found a recruitment rate of 20 to $25 \%$ every 13-18 months and no dispersal of young animals from the area. Except for poachers, there is a virtual lack of predators or other population controls. Unchecked, the Chemehuevi Mountain burro population could double in only 5 years. Such high potential recruitment bespeaks the need for unceasing management and control. The present lack of controls can only lead to overpopulation, degradation of the burro herd incident upon starvation and disease, and the deterioration of the native desert flora and fauna.

\section{Literature Cited}

Browning, B. 1960. Preliminary report of the food habits of the wild burro in the Death Valley National Monument. Desert Bighorn Council Trans. 18:88-90.

Hansen, R. M., and P. S. Martin. 1973. Ungulate diets in the lower Grand Canyon. J. Range Manage. 26:380-381

McMichael, T. J. 1964. Studies of the relationship between desert bighorn sheep and feral burros in the Black Mountains of northwestern Arizona. MS Thesis, Univ. of Ariz. 38 p.

Sparks, D. R., and J. C. Malechek. 1968. Estimating percentage dry weight in diets using a microscopic technique. J. Range Manage. 21:264-265 Weaver, R. A. 1972. Job final report, feral burro survey, project no. W-51-R-17. Dep. Fish and Game, The Resource. Agency, Calif. 8 p Woodward, S. L. 1976. Feral burros of the Chemehuevi Mountains, California: the biogeography of a feral exotic. PhD Diss., Univ. of Calif., Los Angeles. 178 p. 